\title{
Intramedullary cervical cavernous angioma
}

\author{
M. D. Barbosa; A. R. Fernandes; H. Seabra Santos* \\ Departments of Neurosurgery and Neuropathology*, Hospitais da Universidade de Coimbra. Portugal.
}

\section{Abstract}

A case of intramedullary cervical cavernous angioma is presented.

The patient was a 68-year-old man with sensory disturbance as initial symptom, followed by a progressive neurological deficit. Magnetic resonance imaging demonstrated the characteristic pattern of a cavernous angioma. C3-C6 laminectomy, mielotomy, and total removal of the lesion were performed. Transient post operative deterioration was followed by a good functional recovery. Total excision of these lesions should be considered early, before lesions enlargement and recurrent hemorrhage may occur.

KEY WORDS: Cavernous angioma, Carvernoma, Spinal cord, Intramedullary, Complete excision.

\section{Introduction}

Cavernous angioma, or cavernoma, represents a type of vascular malformation of the central nervous system, together with arteriovenous malformations (AVM's), venous malformations and capillary telangiectasias ${ }^{22,31}$.

High definition CT scan ${ }^{1,40}$, and now high field MRI $2 \times 29$, has led to increasing numbers of these lesions being reported.

They remain rare lesions, particularly in the spinal cord $^{2-4,6,9,9,13,19,20,23.25 .26,32.38-41,44}$

The aim of this report is to present a case of an intramedullary cervical cord cavernous angioma which has been radically removed, with good surgical results, and to contribute to a better understanding of the natural history of these unusual lesions.

\section{Case Report}

A 68-year-old man presented with a one and a half year history of progressive left elbow pain and left hand and finger numbness, accompanied by forearms and hands atrophy, gait difficulty, urinary hesitancy and frequency, sexual impotence and, subjectively, cold knees.
On admission, general examination was normal. Neurologically he had an ataxic gait, a spastic tetraparesis, more marked on the right, forearms, hands and right quadriceps wasting, with brisk deep tendon reflexes, a right plantar extensor response, a left hemisensory loss to pain and temperature below D3, and a bilateral decrease in vibration sense below D6.

The clinical impression was that of an intramedullary cervical lesion.

Non constrasted cervical CT scan did not show the lesion.

MRI demonstrated a mixed signal lesion on both T1 and $\mathrm{T} 2$ weighted series, with minimal gadolinium enhancement, at C5 (Fig. 1).

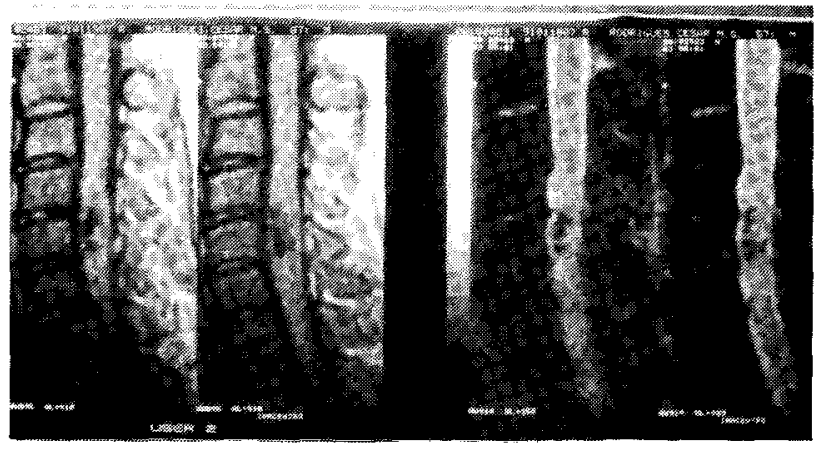

Fig. $1-T 1$ and $T 2$ weighted images, showing the intramedullary cavernous angioma at the C5 level as a low signal intensity lesion with small areas of high signal intensity, on both sequences. There is a slight expansion of the spinal cord.

C3 to C6 laminectomy was performed, without steroid administration due to previous gastrointestinal bleeding. On opening the dura, the CSF was clear and there were no abnormal vessels on the cord surface.

Following partial decompression by removal of a small amount of hemorrhagic fluid, a C5 median mielotomy revealed a dark-blue, lobulated, mulberry-like mass, which extended forwards, to be in contact with the anterior dura.

Total microscopical removal, using bipolar techniques, revealed a circunferencial gliotic plane. 
Postoperatively the patient was undisturbed, but twelve hours post surgery, he developed a dense tetraparesis. After CT scan exclusion of hemorrhage, intravenous steroids were introduced, and, with determined physiotherapy he then made a rapid recovery having achieved normal gait and sphincter function, with power MRC 5 in the legs and 4 in the arms, accompanied by normal tone and tendon reflexes. A C6-D12 suspended pinprick loss persisted.

Follow-up MRI indicated total removal.

Histological appearence was of a cavernoma (Fig. 2).

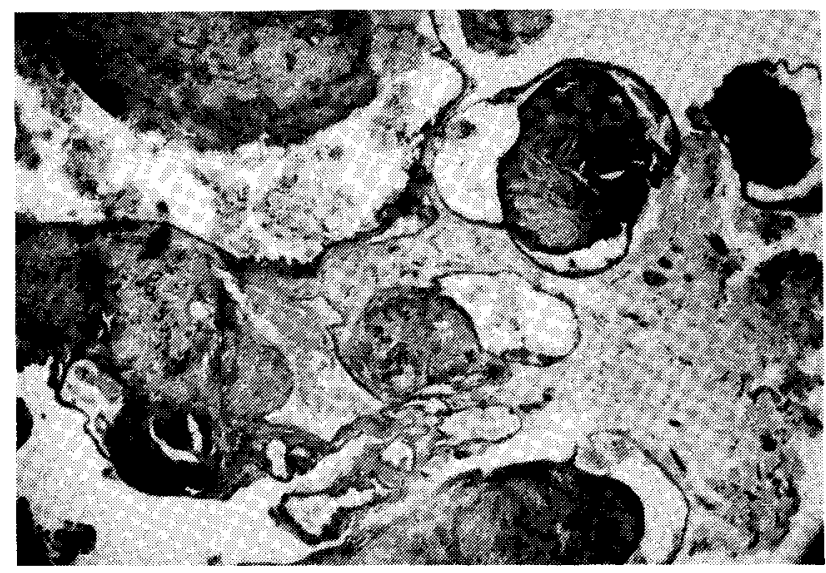

Fig. 2- Photomicrographic appearence of a cavernous angioma, showing large vascular spaces lined by a single layer of endothelium, mostly packed together, but with some neuronal intervening tissue. Parietal and intraluminal masses of fibrous tissue and hyaline collagen, some containing siderophages, are present, both in the vascular spaces and neuronal tissue (Verhoef Van Giesson, x 40).

\section{Discussion}

Cavernous angioma is a relatively rare lesion ${ }^{36,39,41,42,44}$.

They represent $5 \%$ to $13 \%$ of intracranial vascular anomalies ${ }^{36}$. Most commonly described supratentorialy, they have also been reported in the pineal gland ${ }^{12,40}$, IV ventricle ${ }^{7,9,14,15,17,27,43}$ cerebellum ${ }^{36}$, brainstem ${ }^{5,7,14,16,17,24,33,35,36,40}$, cranial nerves ${ }^{21,34,37}$ and spinal nerves ${ }^{11,28,42}$.

They account for $3 \%$ to $16 \%$ of vascular spinal cord anomalies, which in his turn represent $6,2 \%$ to $7,5 \%$ of all intraspinal tumors ${ }^{28,44}$.

Usually located intramedullary, they may be extramedullar, either sub ${ }^{28}$ or extradural ${ }^{18}$.

Thirty seven intramedullary cases, in 36 patients have been reported $2-4,6,10,13,19,20,23,25,26,32,39,40,44$. Thirteen of these were cervical $6,13,20,25,26,32,39,40,44$.

Together with arteriovenous malformations, venous angiomas and telangiectasias, cavernomas are classified as SNC vascular malformations ${ }^{22,31}$. Improved imaging tech- niques, particularly MRI, are demonstrating cavernomas more frequently $2,6,8,18,26,29,33,44,45$.

Clinically the intramedullary cavernomas present in four clinical patterns $26,10,25,26,39,41,44$. The commonest, is discrete episodic neurological deterioration with intervening improvement. Second, slow and progressive neurological deterioration. Third, acute onset of symptoms with progressive deterioration over several days. Lastly, ictal onset of mild symptoms with chronic progressive deterioration lasting weeks to months ${ }^{26}$.

The symptoms reflect location complicated by further intramedullary or subarachnoid hemorrhage, thrombosis, and enlargement by capillary proliferation or hemorrhage inside the lesion ${ }^{5.18,25.26 .364245}$

They may be accompanied by cutaneous hemangiomas, but this is a rare feature ${ }^{38}$.

Macroscopically they are well circumscribed, darkblue, mulberry-like, vascular masses, usually with a surrounding gliotic plane ${ }^{6.182,26,28,41,44}$.

Histologically the cavernomas are characterized by large, closely apposed, irregular, sinusoidal vascular spaces, separated only by sparse collagen or fibrous tissue, usually without intervening neuronal parenchyma $26,33,36,45$. The presence of neuronal parenchyma does not preclude cavernoma. This could suggest a common pathology with telangiectasia ${ }^{30}$.

The vessel walls characteristically lack muscle component, and only scattered elastic elements may be found ${ }^{36}$. They are usually thin, but sometimes endothelium is packed by collagen and hyalinized connective tissue, to form thick, fibrotic vessels ${ }^{26,36}$

Previous hemorrhage is revealed by the presence of cysts, hemosiderin-laden macrophages and cholesterol crystals $26,30,33,36,40,45$.

Recent or old intravascular thrombosis is common ${ }^{26,30,36}$, together with calcium deposits in the thickened vessel walls ${ }^{26,30,33,36,39}$.

The term «Hemangioma calcificans» has been used to describe a lesion, the bulk of which is composed by calcified tissue and metaplasia ${ }^{24,36,39}$.

A formal capsula as well as surrounding gliosis, may be manifest ${ }^{26,36,45}$.

With the increasing knowledge of the natural history of cavernoma, total removal should be considered in each case.

Biopsy and subtotal excision are not satisfactory methods for treating these lesions.

\section{References}

1. Ahmadi, J., Miller, C.A., Segall, H.D., Park, S.H., Zee, C.S., BECKER, R.L.: CT patterns in histopathologically complex cavernous hemangiomas. AJNR 1985; 6: 389-393. 
2. Barnwell, S.L., Dowd, C.F., Davis, R.L., Edwards, .S.B., Gutin, P.H. AND WILsON, C.B.: Cryptic vascular malrmations of the spinal cord: Diagnosis by magnetic resonance aging and outcome of surgery. J. Neurosurg. 1990; 72: 4033 .

3. Bergstrand, A., Hook, O., Lidvall, H.: Vascular malirmations of the spinal cord. Acta Neurol Scand, 1964; 40: 169 33.

4. BiCkNell, J.M., CARLow, T.J., KoRnfield, M., Storving, , TuRNER, P.: Familial cavernous angioma. Arch Neurol. 1978; 5: 746-749.

5. COHEN, H.C.M., TuCKer, W.S., HumPhreys, R.P., PERIN, R.J.: Angiographically cryptic histologically verified cererovascular malformations. Neurosurgery, 1982; 10: 704-714.

6. Cosgrove, G.R., Bertrant, G., Fontaine, S., Robitaille $\therefore$ AND MElanson D.: Cavernous angioma of the spinal cord. J. Jeurosurg, 1988; 68: 31-36.

7. Fahlbusch, R., Strauss, C., Huk, W., Röckelein, G., కÖMPF, D., RUPRECHT, K.W.: Removal of pontomesencephalic avernous hemangiomas. Neurosurgery, 1990; 26: 449-457.

8. Fontaine, S., Melanson, D., CosGrove, M., Bertrand, J.: Cavernous hemangiomas of the spinal cord: MR Imaging. Radiology, 1988; 166: 839-841.

9. Giombini, S., Morello, G.: Cavernous angioma of the orain. Account of fourteen personal cases and review of the liteature. Acta Neurochir (Wien) 1978; 40: 61-82.

10. Goran, A., Carlson, D.J., AND Fisher, R.G.: Successful treatment of intramedullary angioma of the cord. J. Neurosurg. 1964; 21: 311-314.

11. Heimberger, K., Schnaberth, G., Koos, W., Pendl, G., AUFF, E.: Spinal cavernous hemangioma (intradural-extramedullary) underlying repeated subarachnoid hemorrhage. J. Neurol 1978; 226: 289-293.

12. Hubschmann, O., Kasoff, S., Doniger, D., Llina, J., LEED, N.: Cavernous hemangioma in the pineal region. Surg. Neurol. 1976; 6: 349-351.

13. JeLlinger, K.: Pathology of spinal vascular malformation and tumors, in, Pia HW, Djindjian R (eds) Spinal Angiomas: Advances in Diagnosis and Therapy. New York, SpringerVerlag, 1978 (18-44)

14. Kashiwagi, S., Van Loveren, H.R., Tew J.M. JR., WIOT, J.G., WeIL, S.M. AND LuKIN, R.A.: Diagnosis and treatment of vascular brain-stem malformations. J. Neurosurg 1990; 72: $27-34$

15. Kendall, B., Reider-Grosswasser, I., Valentine, A.: Diagnosis of masses within the ventricles on computed tomography. Neuroradiol 1983; 25: 11-22.

16. Kumabe, T., Suzuk1, M., Yoshimoto, T., Suzuki, J.: A case of cavernous angioma extended from the ventral part of the pons to the midbrain: subtemporal and transtentorial approach (in Japanese). No Shinkei Geka, 1989; 16: 1193-1197.

17. Lapras, C., Lapras', C.H., Deruty, R., Patet, J.D., MOTTOLESE, C.: Traitement chirurgical des cavernomes intra-cerebraux. Neurochirurgie, $1989 ; 35: 120-125$.

18. LEE, J.P., WANG, A.D.J., WaI, Y.Y., Ho, Y.S.: Spinal extradural cavernous hemangioma. Surg. Neurol. $1990 ; 34: 345-351$.

19. LEE, K.S., SPETZLER, R.F.: Spinal cord cavernous malformation in a patient with familial intracranial cavernous malformations. Neurosurgery $1990 ; 26: 877-880$.
20. Lopate, G., Black, J.T., GrubB, R.L.: Cavernous hemangioma of the spinal cord: Report of 2 unusual cases. Neurology, 1990; 40: 1791-1793.

21. Matias-Guiu, X., Alejo, M., Sole, T., Ferrer, I., NoBOA, R., BARTUMEUS, F.: Cavernous angiomas of the cranial nerves. Report of two cases. J. Neurosurg, 1990; 73: 620-622.

22. MCCormick, W.F.: The pathology of vascular («arterio venous») malformations. J. Neurosurg, 1966; 24: 807-816.

23. McCormick, P.C., Michelsen, W.J., Post, K.D., CaRMEL, P.W., SteIN, B.M.: Cavernous malformations of the spinal cord. Neurosurgery, 1988; 23: 459-463.

24. Occhiogrosso, M., Carella, A., D' Aprile, P., Vailati, G.: Brainstem hemangioma calcificans. Case report. J. Neurosurg, 1983; 59: 150-152.

25. Odom, G.L., Hall, B.W., Margolis, G.: Spontaneous hematomyelia and angiomas of the spinal cord. J. Neurosurg. 1957; 14: 192-202.

26. Olgivy, C.S., Louis, D.N., OJemanN, R.G.: Intramedullary cavernous angiomas of the spinal cord: clinical presentation, pathological features and surgical management. Neurosurgery, 1992; 31: 219-230.

27. Ondra, S.L., Doty, J.R., Mahla, M.E., George, E.D.: Surgical excision of a cavernous hemangioma of the rostral brainstem: Case report. Neurosurgery, 1988; 23: 490-493.

28. Pagni, C.A., Canavero, S., Forni, M.: Report of a cavernoma of the cauda equina and review of the literature. Surg. Neurol. 1990; 33: 124-131.

29. Rigamonti, D., Drayer, B.P., Johnson, P.C., Hadley, M.N., ZaBRAMSKI, J. AND SPETZleR, R.F.: The MRI appearance of cavernous malformations (angiomas). J. Neurosurg. 1987; 67: 518-524.

30. Rigamonti, D., Johnson, P.C., Spetzler, R.F., Hadley, M.N. AND DRAYER, B.P.: Cavernous malformations and capillary telangiectasia: A spectrum within a single pathological entity. Neurosurgery, 1991. 28: 60-64.

31. Russel, D.S., RuBinStein, J.L.: Pathology of Tumors of the Nervous System. ed 4, Baltimore. Williams \& Wilkins, 1977 (116-45)

32. Saito, N., Yamakawa, K., Sasaki, T., Saito, I., TaKaKURA, K.: Intramedullary cavernous angioma with trigeminal neuralgia: A case report an review of the literature. Neurosurgery, 1989; 25: 97-101.

33. Sakai, N., Yamada, H., Tanigawara, T. Asano, Y., ET AL: Surgical treatment of cavernous angioma involving the brainstem and review of the literature. Acta Neurochir (Wien), 1991; 113: 138-143.

34. SCOTT, R.M.: Third nerve palsy in a 14-year-old boy due to cavernous angioma of the third nerve. In Raimondi AJ (ed). Concepts in Pediatric Neurosurgery 3. New York, Karger, 1983 (100-107)

35. Seifert, V., GAAB, M.R.: Laser-assisted microsurgical extirpation of brainstem cavernoma: Case report. Neurosurgery, 1989; 25: 986-990.

36. Simard, J.M., Garcia-Bengochea, F., Ballinger, W.E., MickLE, J.P., QUISLING, R.G.: Cavernous angioma. A review of 126 collected and 12 new clinical cases. Neurosurgery, 1986; 18: 162-172.

37. Sundaresan, N., Eller, T., Ciric, I.: Hemangiomas of the internal auditory canal. Surg. Neurol, 1976; 119-121. 
38. SzoJCHET, A.: Metameric spinal cord and skin hemangiomas. Case report. J. Neurosurg, 1968; 29: 199-201.

39. Tyndel, F.J., Bilbao, J.M., Hudson, A.R., Colapinto, E.V.: Hemangioma calcificans of the spinal cord. Can J Neurol Sci, $1985 ; 12: 321-322$.

40. Vaquero, J., Salazar, J., Martinez, R., Martinez, P., Bravo, G.: Cavernomas of the central nervous system: clinical syndromes, CT scan diagnosis, and prognosis after surgical treatment in 25 cases. Acta Neurochir, 1987; 85: 29-33.

41. Vaquero, J., Martinez, R., Martinez, P.: Cavernomas of the spinal cord. Report of two cases. Neurosurgery, 1988; 22: 143-144.

42. Ueda, S., SaIto, A., Indmori, S., KIM, I.: Cavernous angioma of the cauda equina producing subarachnoid hemorrhage. Case report. J. Neurosurg, 1987; 66: 134-136.

43. Yosнimoto, T., SUZUKI, J.: Radical surgery on cavernous angioma of the brainstem. Surg. Neurol, 1986; 26: 72-78.
44. Zenter, J., Hassler, W., Gawehn, J., Schroth, G.: Intramedullary cavernous angiomas. Surg. Neurol, 1989; 31: 6468.

45. Zimmerman, R.S., SpetZl.er, R.F., LeE, K.S., ZabransKI, J.M., HaRgraves, R.W.: Cavernous malformations of the brain stem. J. Neurosurg, 1991; 75: 32-35.

Barbosa, M.D.; Fernandes, A.R.; Seabra Santos, H.: Intramedullary cervical cavernous angioma. Neurocirugía 1993; 4: 321-324. 